\title{
ZEZWOLENIA NA DETALICZNĄ SPRZEDAŻ NAPOJÓW ALKOHOLOWYCH: OPTYMALIZACJA PROCEDURY ICH WYDAWANIA
}

\author{
I. KRYTYCZNA OCENA ART. 18 UST. 1 \\ W ZW. Z UST. 2 I 3A U.ALKOHOL. ${ }^{1}$
}

Uznanie administracyjne jest instytucją (kategoria) prawną na tyle utrwaloną w języku prawniczym, że analizy i spory koncentrują się na zagadnieniach szczegółowych ${ }^{2}$. Używając skrótu myślowego, można powiedzieć, że uwaga dzisiejszych dyskutantów i sądów administracyjnych koncentruje się na ocenie prawidłowości wykorzystania uznania administracyjnego do kształtowania treści decyzji administracyjnej. Stawiane sa pytania o kolejne etapy wnioskowania organu administracyjnego, poczynając od wykładni podstawy prawnej decyzji, poprzez gromadzenie i ocenę materiału dowodowego, subsumcję faktów do hipotezy normy prawnej, aż po punkt krytyczny dla uznaniowego załatwiania sprawy, jakim jest konkretyzacja abstrakcyjnej dyspozycji podstawy prawnej celem ustalenia obowiazków lub/i uprawnień adresata decyzji konstytutywnej. Dla takiego punktu widzenia reprezentatywny jest bipolarny materialny stosunek administracyjnoprawny, łączący organ administracyjny wyłącznie z adresatem decyzji. Nawet wówczas, gdy organ załatwia sprawę administracyjną sporną między stronami (np. sąsiad inwestora wnosi odwołanie od pozwolenia na budowę, ponieważ obawia się obniżenia wartości swej działki w efekcie podjęcia przez inwestora uciążliwej działalności gospodarczej w zamierzonym obiekcie), dominuje przekonanie, że nie ma podstaw do mówienia o trójstronnym stosunku materialnym (łączącym inwestora, sąsiada i organ), a jedynie o dwóch równoległych stosunkach (organ-inwestor, organ-sasiad). Takie stanowisko jest wzmocnione przez art. 62 k.p.a. ${ }^{3}$ pozostawiający w gestii organu możliwość prowadzenia jednego postępowania

${ }^{1}$ Ustawa z 26 października 1982 r. o wychowaniu w trzeźwości i przeciwdziałaniu alkoholizmowi, Dz. U. 2013, poz. 672 ze zm. (dalej jako: u.alkohol.; artykuły powoływane bez oznaczenia aktu normatywnego sa przepisami tej ustawy).

${ }^{2}$ L. Leszczyński, Interpretacyjna rola kryteriów otwartych $i$ innych decyzji stosowania prawa, w: System prawa administracyjnego, t. 4: Wyktadnia w prawie administracyjnym, red. R. Hauser, Z. Niewiadomski, A. Wróbel, Warszawa 2012, rozdział X; B. Wojciechowski, Model zakresu swobody interpretacyjnej prawa administracyjnego, w: System..., t. 4, rozdział VII.

${ }^{3}$ Ustawa z 14 czerwca 1960 r. - Kodeks postępowania administracyjnego, Dz. U. 2013, poz. 267 ze zm. (dalej jako: k.p.a.). 
„w sprawach, w których prawa lub obowiązki stron wynikają z tego samego stanu faktycznego oraz z tej samej podstawy prawnej i w których właściwy jest ten sam organ administracji publicznej”.

Proste, żeby nie powiedzieć dosłowne, zastosowanie tego modelu stosowania (konkretyzacji) normy prawa administracyjnego materialnego do wydawania przez wójta gminy zezwolenia na detaliczną sprzedaż napojów zawierających więcej niż 4,5\% alkoholu (art. 18 ust. 1 w zw. z ust. 2 i 3 a ustawy ${ }^{4}$ ) leżało u podstaw praktyki organów I instancji, która została zakwestionowana jako naruszająca interesy prawne przedsiębiorców, którym odmówiono zezwolenia. Wójt gminy, majacc możliwość wydania tylko jednego zezwolenia (w ramach gminnego limitu ilości punktów sprzedaży napojów alkoholowych ${ }^{5}$ ) uwzględniał tylko jeden wniosek. Pozytywne załatwienie tego wniosku było następnie przywoływane przez tenże organ w pozostałych odmownych decyzjach dla uzasadnienia negatywnego rozstrzygnięcia. Postępowania odwoławcze, wszczęte przez niezadowolonych handlowców, były przez organy wyższego stopnia umarzane, ,jako bezprzedmiotowe, gdyż wnoszacy odwołanie nie uzyskali przymiotu strony postępowania, nie mogą się wykazać interesem prawnym w sprawie innego przedsiębiorcy"6. Taki punkt widzenia podzielił sąd administracyjny stwierdzając, że „organ administracyjny ni e p o wi ni e n [wyróż. - W.K.] uzależniać rozstrzygnięcia sprawy jednego podmiotu wnioskującego o przyznanie zezwolenia od wyniku sprawy prowadzonej z wniosku drugiego podmiotu złożonego w tym samym okresie"

Równocześnie jednak sąd uznał konieczność prowadzenia w takich przypadkach jednego postępowania, mającego za przedmiot jedną sprawę administracyjna. Sąd nawiązał w ten sposób do stanowiska doktryny, w której „dość powszechnie akceptowany jest pogląd, wedle którego wykluczajace się wzajemnie żądania kilku podmiotów, skierowane na wydanie decyzji w odniesieniu do tego samego przedmiotu, powinny być rozpoznane i rozstrzygnięte łącznie, we wspólnym postępowaniu. Są one - zdaniem badaczy - elementami jednej, złożonej pod względem podmiotowym, sprawy administracyjnej"s. W takim ujęciu jedność sprawy administracyjnej i postępowania administracyjnego nie skutkuje nawiązaniem więzów materialnoprawnych między stronami spornego postępowania jurysdykcyjnego.

\footnotetext{
${ }^{4}$ „Sprzedaż napojów alkoholowych [...] może być prowadzona tylko na podstawie zezwolenia wydanego przez wójta (burmistrza, prezydenta miasta), właściwego ze względu na lokalizację punktu sprzedaży" (art. 18 ust. 1 u.alkohol.)

${ }^{5}$ „Rada gminy ustala, w drodze uchwały, dla terenu gminy (miasta) liczbę punktów sprzedaży napojów zawierających powyżej 4,5\% alkoholu (z wyjątkiem piwa), przeznaczonych do spożycia poza miejscem sprzedaży jak i w miejscu sprzedaży" (art. 12 ust. 1 u.alkohol.).

${ }^{6}$ Decyzja SKO w Toruniu z 16 grudnia 2011 r., SKO-50-88/11, cytowana w wyroku WSA w Bydgoszczy z 29 września 2010 r., II SA/Bd 612/10 (wyroki sądów administracyjnych dostępne są w Centralnej Bazie Orzeczeń Sądów Administracyjnych: http://orzeczenia.nsa.gov.pl/).

${ }^{7}$ Wyrok WSA w Bydgoszczy z 30 stycznia 2012 r., II SA/Bd 1284/11 z glosą autora, „Przegląd Prawa Publicznego" 2013, nr 1(71).

${ }^{8}$ T. Kiełkowski, Wspótuczestnictwo konkurencyjne w postepowaniu koncesyjnym, „Państwo i Prawo" 54, 1999, z. 11, s. 45; B. Adamiak, Komentarz do art. 62, w: B. Adamiak, J. Borkowski, Kodeks postepowania administracyjnego. Komentarz, Warszawa 2003, s. 344-345; J. Zimmermann, Polska jurysdykcja administracyjna, Warszawa 1996, s. 76.
} 
Taki typ interpretacji art. 18 ustawy został zakwestionowany, gdy dostrzeżono istotne znaczenie prawne konfliktu między interesami prawnymi przedsiębiorców składających więcej wniosków niż można ich w tym momencie uwzględnić. Sąd wskazał ${ }^{9}$, że w efekcie wydania w sprawie odrębnych 21 decyzji rozstrzygających oddzielnie o każdym z 21 wniosków motywy każdego rozstrzygnięcia zostały przedstawione oddzielnie w każdej z 21 decyzji, bez ujawnienia ich pozostałym 20 stronom. Żaden ze skarżących się na decyzje odmowne nie mógł skutecznie podjaćc polemiki z organem, aby móc wykazać nieprawidłowość wyboru innego wnioskodawcy, któremu udzielono zezwolenie. Sąd zwrócił uwagę, że w ten sposób, decyzje organu odwoławczego stały się rozstrzygnięciami faktycznie niezaskarżalnymi (!). Decyzji negatywnej jej adresat nie mógł skutecznie zwalczać skargą do sądu administracyjnego. Nawet bowiem uchylenie tej decyzji negatywnej nie mogło doprowadzić do przyznania tej stronie zezwolenia, skoro jedyne możliwe zezwolenie już dawno się uprawomocniło, a co najmniej - pozostało decyzją ostateczna, niezaskarżona do sądu administracyjnego ${ }^{10}$. Sąd odnotował, że przedsiębiorcy otrzymującemu decyzję negatywną odmawiano legitymacji do zaskarżenia decyzji pozytywnej, albowiem ta ostatnia nie była skierowana do tego skarżącego, nie kształtowała jego sytuacji prawnej, lecz przyznawała uprawnienie innemu podmiotowi. Taką sytuację Sąd uznał za naruszenie norm konstytucyjnych, zapisanych w art. 32 ust. 1 i art. 45 ust. 1 Konstytucji RP w związku z art. 15 i art. 127 $\S 1$ k.p.a. ${ }^{11}$

Samo tylko zmodyfikowanie sposobu procedowania nie rozwiązuje istoty problemu, jaki jest przedmiotem niniejszej analizy. Mówiąc skrótowo i z dużym uproszczeniem, niemalże do każdej decyzji można post factum dopisać perfekcyjne uzasadnienie, które będzie miało szansę na aprobatę sądu administracyjnego. Sacdowa kontrola decyzji wydawanych w tego rodzaju sprawach zawsze pozostanie zaledwie uzupełnieniem znacznie szerszego uregulowania omawianej tu problematyki, uzupełnieniem wprawdzie koniecznym, ale zdecydowanie nie wystarczającym. Potrzebne jest połaczenie uznaniowego charakteru decyzji - z jednej strony - z bezstronnością organu właściwego w sprawie $^{12}$ i transparentnością postępowania administracyjnego poprzedzajacego

\footnotetext{
${ }^{9}$ Wyrok WSA w Bydgoszczy z 30 stycznia 2012 r., II SA/Bd 1284/11.

10 „Prawomocność [...] powinna być rozumiana jako cecha przysługująca wyłącznie decyzjom i postanowieniom wydanym w postępowaniu jurysdykcyjnym, egzekucyjnym i zabezpieczającym, które zostały zaskarżone do sądu administracyjnego i przez ten sąd utrzymane w mocy jako zgodne z prawem w rezultacie wydania przez ten sąd wyroku oddalającego skargę na podstawie art. 151. [...] Prawomocność jest więc szczególną kwalifikacją decyzji ostatecznej, którą uzyskuje ona w efekcie utrzymania jej w mocy przez sąd administracyjny, jako zgodnej z prawem w zakresie, w jakim sąd ten dokonuje tej kontroli. Takich kwalifikacji nie uzyskują żadne inne decyzje”, T. Woś, Prawomocność zaskarżonego aktu (czynności) jako efekt oddziatywania wyroku sqdu oddalajacego skargę, w: T. Woś (red.), H. Knysiak-Molczyk, M. Romańska, Postęowanie sqdowoadministracyjne, wyd. 5, Warszawa 2011, s. 355-356.

11 Wyrok WSA w Bydgoszczy z 13 sierpnia 2013 r., II SA/Bd 385/13 - syntetycznie przypominający motywy wyroku WSA w Bydgoszczy z 29 września 2010 r., II SA/Bd 612/10.

12 Sąd był zdania, że określenie kryteriów niezbędnych do wydania zezwolenia powinno być obiektywne, jasne i precyzyjne, a procedura wyboru przejrzysta i poddająca się kontroli, tak aby zadośćuczynić zasadom postępowania administracyjnego (wyrok NSA z 24 lipca 2013 r., II
} 
wydanie takiej decyzji - z drugiej strony. W jaki sposób wójt gminy ma wybrać tego wnioskodawcę, któremu wyda zezwolenia, aby na organ nie padł nawet cień podejrzenia, że kryteria wyboru uwzględnianego wniosku sformułowano stronniczo, tak aby zezwolenie otrzymał wcześniej „wybrany”, uzgodniony przedsiębiorca? Zagrożenie korupcyjnym „motywowaniem” organu, mającym przesądzić o wyniku postępowania jeszcze przed jego rozpoczęciem, jest w tych sprawach bardzo wyraźne, albowiem sprzedaż alkoholu jest zawsze bardzo dochodowa. Zezwolenia wójta gminy na detaliczną sprzedaż napojów alkoholowych powinny być efektem takich procedur, które będą transparentne, a przez to - poddajace się wszechstronnej i skutecznej kontroli przez wszystkie zainteresowane osoby. Ta kontrola powinna być możliwa na bieżąco, na każdym etapie kształtowania gminnej polityki w odniesieniu do sprzedaży napojów alkoholowych, jak i w toku przygotowywania indywidualnych decyzji.

Uzasadnione jest bardziej uważne przyjrzenie się sytuacji poprzedzającej wydanie pozwolenia, a w szczególności - uprzedniemu opiniowaniu wniosków przez gminną komisję rozwiązywania problemów alkoholowych (art. 18 ust. $3 \mathrm{a}^{13}$ ). Nasuwają się wątpliwości, czy komisja powinna się ograniczać wyłącznie do opiniowania wniosków stron pod względem ich zgodności z uchwałami rady gminy określającymi (a) liczbę punktów sprzedaży napojów alkoholowych na terenie gminy oraz (b) zasady ich usytuowania.

\section{UZNANIOWY CHARAKTER POZWOLENIA NA DETALICZNĄ SPRZEDAŻ NAPOJÓW ALKOHOLOWYCH}

Kluczowe znaczenie dla praktyki administracyjnej i orzecznictwa sądów administracyjnych ma zaliczenie zezwolenia na detaliczną sprzedaż napojów alkoholowych do aktów administracyjnych uznaniowych. Taka kwalifikacja zezwoleń jest do tego stopnia utrwalona w orzecznictwie sądów administracyjnych ${ }^{14}$, że uzasadnienia wyroków najczęściej nie zawierają szczegółowej argumentacji przemawiającej na rzecz takiego stanowiska. Skoro jednak charakter prawny zezwoleń przewidzianych w art. 18 ust. $1 \mathrm{w}$ zw. z ust. 2 i $3 a$ ustawy ma być punktem odniesienia oceny adekwatności tych przepisów ustawy oraz postulatów de lege ferenda, to warto zweryfikować taką ocenę.

GSK 605/12); podobne ujęcie obowiązków organu właściwego w sprawie akcentują Z. Czarnik, W sprawie pozycji prawnej Państwowej Inspekcji Pracy, „Państwo i Prawo” 65, 2010, z. 10, s. 111; M. Pułło, Glosa do wyroku NSA z 22 marca 2012 r., I FSK 876/11, „Orzecznictwo Sąów Polskich" 2013, z. 1, s. 63.

${ }^{13}$ „Zezwolenia [na sprzedaż napojów alkoholowych] organ zezwalający wydaje po uzyskaniu pozytywnej opinii gminnej komisji rozwiązywania problemów alkoholowych o zgodności lokalizacji punktu sprzedaży z uchwałami rady gminy, o których mowa w art. 12 ust. 1 i 2 [określającymi liczbę punktów sprzedaży napojów alkoholowych oraz zasady usytuowania na terenie gminy miejsc sprzedaży i podawania napojów alkoholowych - dop. W.Z.]" (art. 18 ust. 3a u.alkohol.).

${ }_{14}$ „W orzecznictwie i w doktrynie ugruntowany jest podgląd, że decyzje wydawane na podstawie art. 18 ustawy o wychowaniu w trzeźwości mają charakter uznaniowy, ale o ograniczonym zakresie uznania administracyjnego" (wyrok NSA z 24 czerwca 2013 r., II GSK 605/12). 
Doktryna prawnicza nie pozostawia żadnych wattpliwości, że uznanie administracyjne jest konieczne $\mathrm{w}$ prawie administracyjnym demokratycznego państwa prawnego, zdaje sobie jednak sprawę z faktu, że ustawowa definicja tej instytucji jest niemożliwa ${ }^{15}$. Źródła władzy dyskrecjonalnej upatruje się najczęściej w niedookreślonych pojęciach prawnych, użytych w podstawie prawnej aktu administracyjnego ${ }^{16}$. Tymczasem w art. 18 ust. $1 \mathrm{w}$ zw. z ust. 2 i $3 \mathrm{a}$ ustawy nie ma żadnego pojęcia nieoznaczonego: „Sprzedaż napojów alkoholowych [...] może być prowadzona tylko na podstawie zezwolenia wydanego przez wójta [...]” (ust. 1). Słowa „może być prowadzona” oznaczają przede wszystkim bezwzględny zakaz handlu napojami alkoholowymi, który jest uchylany w odniesieniu do tych podmiotów, które otrzymały indywidualne zezwolenie tylko na czas ważności tej decyzji i we wskazanym tam lokalu. Przedsiębiorca, składając wniosek o wydanie zezwolenia, ma w najlepszym razie interes prawny w sprawie, który nie gwarantuje jednak pozytywnej decyzji. Co więcej, ustalenie przez radę gminy liczby punktów sprzedaży napojów alkoholowych (art. 12 ust. 1 ustawy) nie nakłada na wójta gminy bezwzględnego obowiązku zagwarantowania, że przez cały rok ten limit będzie w całości wyczerpany.

Sądowa kontrola powyższych decyzji koncentruje się na ocenie postępowania wyjaśniającego prowadzonego przez gminną komisję rozwiązywania problemów alkoholowych i przez wójta gminy, jego subsumcji ustalonego stanu faktycznego do hipotezy normy prawnej i zgodności zastosowania dyspozycji podstawy prawnej z wszelkimi rygorami legalności. Miał więc rację sąd, akcentujac brak „swobody” decyzyjnej organu administracyjnego, jeżeli miałaby ona być rozumiana jako zwolnienie właściwego organy od wszelkich ograniczeń: „W demokratycznym państwie prawa, jakim z mocy art. 2 Konstytucji jest Rzeczypospolita Polska, nie istnieje kategoria swobodnego uznania administracji [albowiem - dop. W.K.] każde rozstrzygnięcie organów administracji publicznej powinno być oparte na konkretnej podstawie prawnej oraz zostać wydane po rozważeniu całego materiału dowodowego w danej sprawie" ${ }^{17}$. Nie ma sporu w doktrynie ani odstępstw od utrwalonej linii orzecznictwa sądów administracyjnych, że każda decyzja administracyjna musi być efektem racjonalnego wnioskowania właściwego organu, uwzględniającego stan faktyczny i prawny sprawy.

Taki stan rzeczy nie podważa jednak zasadności, ani zapotrzebowania na podział decyzji na konstytutywne (uznaniowe) i deklaratoryjne oraz nie niweluje uznaniowego charakteru zezwolenia pomimo braku pojęcia nieoznaczonego w jego podstawie prawnej. Uznaniowość tego zezwolenia jest efektem lapidarności powołanego przepisu, który w różnych gminach umożliwia właściwym miejscowo wójtom gminy stosowanie własnych kryteriów wyboru uwzględnionego wniosku, stosownie do realizowanej przez siebie polityki reglamentowania w danej gminie sprzedaży napojów alkoholowych. De lege lata w ramach jurysdykcyjnego postępowania administracyjnego, koniecznego dla

${ }^{15}$ J. Zimmermann, Opinia prawna na temat projektu ustawy Przepisy ogólne prawa administracyjnego, „Zeszyty Prawnicze Biura Analiz Sejmowych” 2010, nr 2(26), s. 35 i 42.

${ }^{16}$ B. Wojciechowski, op. cit.

${ }^{17}$ Wyrok WSA w Kielcach z 31 października 2012 r., II SA/Ke 595/12. 
wydania zezwolenia na detaliczną sprzedaż napojów alkoholowych, właściwy wójt gminy (1) ustala kryteria selekcji wniosków, (2) ustala, który wniosek zostanie załatwiony pozytywnie, (3) stosownie do tego wyboru wydaje jedno lub więcej zezwoleń na prowadzenie sprzedaży oraz (4) odmownie załatwia pozostałe wnioski. Objęcie jedna procedura, prowadzona przez pojedynczego wójta gminy zarówno konstytutywnego, uznaniowego ustalenia kryteriów selekcji wniosków, jak i zastosowanie owych kryteriów do ustalenia treści jego decyzji przesądza uznaniowy charakter zarówno pozytywnego zezwolenia, jak i negatywnej odmowy. Takiej kwalifikacji owych decyzji nie modyfikuje w najmniejszym zakresie przestrzeganie przez wójta gminy standardów demokratycznego państwa prawnego i szczegółowych rygorów procedury jurysdykcyjnej.

\section{KONFLIKT INTERESÓW PRAWNYCH STRON}

Narzucając zainteresowanym przedsiębiorcom reglamentację sprzedaży, ustawodawca generuje konflikt interesu gminy, zainteresowanej opłatami za korzystanie z zezwoleń (art. 111), z interesami finansowymi przedsiębiorców. Ustalając liczbę zezwoleń na poziomie niższym od liczby przedsiębiorców zainteresowanych handlem napojami alkoholowymi (art. 12 ust. 1), gmina przesadza o pojawieniu się dodatkowego konfliktu, tym razem pomiędzy interesami prawnymi owych wnioskodawcó $\mathrm{w}^{18}$. W takim kontekście istotnego znaczenia nabiera postulat zasadniczego zwiększenia transparentności analizowanej tu reglamentacji sprzedaży. Przepisy ustawy o wychowaniu w trzeźwości i przeciwdziałaniu alkoholizmowi powinny być służebne wobec kodeksowej zasady sprawności załatwiania wniosków o zezwolenie (art. 12 k.p.a.), ale w równym stopniu - wobec konstytucyjnego wymogu równego traktowania podmiotów przez władze publiczne ${ }^{19}$. W omawianym zakresie oznacza to równy dostęp zainteresowanych przedsiębiorców do reglamentowanego dobra (zezwolenia) oraz ochrony tych procedur przed patologiami korupcyjnymi. Sprzedaż napojów alkoholowych jest dla przedsiębiorców tak atrakcyjnym źródłem przychodu, że niebezpieczeństwo korupcji musi być brane pod uwage przy ocenie obowiąującego prawa i formułowaniu propozycji de lege ferenda.

Orzecznictwo sądów administracyjnych wielokrotnie już akcentowało, że decyzje uznaniowe nie mogą być arbitralne ${ }^{20}$, a wręcz przeciwnie - powinny

${ }^{18}$ Szerzej na temat współuczestnictwa konkurencyjnego por. W. Kisiel, Glosa do wyroku WSA w Bydgoszczy z 30 stycznia 2012 r., II SA/Bd 1284/11, „Przegląd Prawa Publicznego” 2013, nr 1(71), s. 92-101.

19 „Wszyscy mają prawo do równego traktowania przez władze publiczne” (art. 32 ust. 1 zd. 2 Konstytucji RP).

${ }^{20}$ „[O]rgan nie mógł podjąć arbitralnej decyzji tylko na podstawie ogólnego powołania tego przepisu. Organ [...] powinien wskazać konkretny przepis, którego dyspozycję uznał za naruszona oraz wykazać, na czym to pogwałcenie konkretnej normy prawnej polega" (wyrok WSA w Olsztynie z 12 marca 2008 r., II SA/Ol 42/08); por. również: wyroki NSA z 6 października 2011 r., I OSK 
być racjonalne. Organ administracyjny w uzasadnieniu decyzji oraz w postępowaniu przed sądem administracyjnym powinien w przekonujacy sposób wykazać, że dokonany wybór treści decyzji jest optymalny w okolicznościach faktycznych sprawy. Organ administracyjny powinien przekonać strony (art. 11 k.p.a.), a następnie sąd administracyjny (art. $54 \S 2^{21}$ i art. $106 \S 2$ p.p.s.a. ${ }^{22}$ ), że wydana decyzja jest nie tylko zgodna z litera obowiąującego prawa, ale również - w optymalny sposób rozstrzyga konflikt sprzecznych interesów prawnych wnioskodawców. Jeżeli w konkretnym postępowaniu jurysdykcyjnym organ administracyjny nie miał faktycznych możliwości zaspokojenia interesów wszystkich zainteresowanych stron, to organ musi dołożyć należytej staranności, aby wybrać wniosek, który w największym stopniu spełnia wzorzec przyjęty dla danej sprawy, czyli kryteria wyboru przedsiębiorcy mającego otrzymać zezwolenie.

Decyzje te rozstrzygają konflikt interesów prawnych kilku(nastu) wnioskodawców ubiegających się równocześnie o pojedyncze zezwolenie. Jeżeli wójt gminy może udzielić zezwolenia tylko jednemu wnioskodawcy, to uwzględnienie jednego wniosku jest równoznaczne $\mathrm{z}$ odmownym załatwieniem wszystkich pozostałych wniosków, jakie wpłynęły i były przedmiotem postępowania. $\mathrm{Z}$ tego względu newralgicznego znaczenia nabiera ustalenie adekwatnego momentu czasowego dla ustalenia kryteriów wyboru przedsiębiorcy otrzymującego zezwolenie. Ma to kluczowe znaczenie dla obiektywizmu i profesjonalizmu załatwienia wniosków.

De lege lata nie ma żadnych przeszkód, aby te kryteria wójt gminy ustalał dopiero w ostatniej fazie postępowania zmierzającego do wydania zezwolenia, czyli już po zapoznaniu się z całością akt sprawy administracyjnej. Tymczasem bezstronność organu w wyborze kryteriów, czyli wykluczenie podejrzenia, że kryteria są zredagowane celem pozytywnego załatwienia konkretnego wniosku, jest o wiele bardziej prawdopodobne, gdy kryteria będą ustalone jeszcze przed wpłynięciem pierwszego wniosku i następne etapy postępowania będą jawne w równym stopniu wobec wszystkich stron ubiegajacych się o zezwolenie. Uznanie administracyjne, rozumiane jako świadome wybieranie konsekwencji prawnych zastosowania dyspozycji podstawy ustawowej celem ustalenia treści decyzji administracyjnej, jest postrzegane jako istota administrowania w najlepszym tego słowa znaczeniu i przeciwstawiane kazuistyce prawa $^{23}$.

1510/11 oraz z 7 lipca 2010 r., I OSK 592/10; wyrok WSA we Wrocławiu z 8 października 2014 r., II SA/Wr 541/14; wyrok WSA w Kielcach z 31 października 2012 r., II SA/Ke 595/12; wyrok WSA w Białymstoku z 13 kwietnia 2006 r., II SA/Bk 83/06.

${ }^{21}$ „Organ [...] przekazuje skargę sądowi wraz z aktami sprawy i odpowiedzią na skargę w terminie trzydziestu dni od dnia jej wniesienia", art. 54 § 2 ustawy z 30 sierpnia 2002 r. - Prawo o postępowaniu przed sądami administracyjnymi, Dz. U. 2012, poz. 270 ze zm. (dalej jako: p.p.s.a.).

${ }^{22}$ „Po złożeniu sprawozdania, strony - najpierw skarżący, a potem organ - zgłaszają ustnie swoje żądania i wnioski oraz składają wyjaśnienia”, art. $106 \S 2$ zd. 1 p.p.s.a.

${ }^{23}$ Zdaniem M. Dziurdy kazuistyczne uregulowania prawne „zawsze naruszają spójność systemu prawa”, idem, Opinia prawna w sprawie poselskiego projektu ustawy o zmianie ustawy - Prawo o postepowaniu przed sqdami administracyjnymi i niektórych innych ustaw, „Zeszyty Prawnicze" 2014, nr 1(41), s. 234-235. 
Jeżeli wybór organu wydającego decyzję dokonywany jest na zasadzie alternatywy rozłącznej (jedno zezwolenie jest równoznaczne z odmownymi decyzji dla pozostałych wnioskodawców), a zezwolenie ma znacząca wartość finansowa dla stron, to zabezpieczenie bezstronności organu właściwego w sprawie wymaga, aby (1) wybór wspomnianych kryteriów został przesądzony i podany do publicznej wiadomości jeszcze przed ogłoszeniem „zaproszenia" do składania wniosków o przyznanie zezwolenia na sprzedaż, (2) po wszczęciu postępowania zmierzającego do wydania zezwolenia zestaw tych kryteriów nie mógł być przez wójta gminy zmieniany ani uzupełniany. Innymi słowy, należałoby wyraźnie oddzielić od siebie dwa etapy stosowania ustawy: (1) określenie polityki, czyli kryteriów rozdziału zezwoleń na sprzedaż napojów alkoholowych w gminie, oraz (2) załatwienie wniosków o zezwolenie. Realizacja powyższego „rozparcelowania” procesu decyzyjnego jest możliwa już na gruncie prawa obowiąującego. Jest to jedynie możliwość, a nie bezwzględny obowiazek organu administracyjnego. Dlatego ujawnienie przez wójta gminy kryteriów wyboru uwzględnionego wniosku dopiero w uzasadnieniu decyzji o przyznaniu zezwolenia nie może być uznany przez sąd administracyjny za takie naruszenie procedury administracyjnej, które mogło mieć istotny wpływ na wynik postępowania administracyjnego. Przedstawiony tu model procedowania nie pozostaje w sprzeczności z wymogiem sprawności w załatwianiu wniosków stron. Polityka zezwoleń nie jest (a przynajmniej nie powinna być) kształtowana doraźnie; przeciwnie - powinna zawsze brać pod uwagę co najmniej wielomiesięczny horyzont czasowy. Okoliczności faktyczne, które trzeba uwzględnić przy wydawaniu zezwoleń na sprzedaż napojów alkoholowych, również nie są niespodzianką dla wójta gminy w dniu zakończenia postępowania ${ }^{24}$. W większości gmin zezwolenia, o jakich tu mowa, sa regularnie wydawane kilka razu do roku. Nie powinno być więc najmniejszego problemu w określeniu kryteriów jeszcze przed napływem wniosków, aby kryteria spełniły swoją rolę w procedurze rozpatrywania wniosków o wydanie zezwolenia. Praktyka funkcjonowania Prawa o zamówieniach publicznych ${ }^{25}$ świadczy o tym, że takie wcześniejsze ogłoszenie kryteriów nie gwarantuje całkowicie, że procedura nie będzie „ustawiona” pod konkretnego przedsiębiorcę. Przecież jednak taka jawność w istotnym zakresie podnosi poziom zabezpieczenia interesu publicznego.

\section{PROPOZYCJA KONKURSU WNIOSKÓW}

Newralgiczne znaczenie ma organizacja procedury załatwiania indywidualnych wniosków. Jak wspomniano wyżej w punkcie I, dopiero niedawno zakwestionowano dopuszczalność rozpatrywania każdego z wniosków w odrębnym postępowaniu, w którym pozostali wnioskodawcy ubiegający się o zezwolenie $\mathrm{w}$ tym samym czasie nie byli stronami. Wskazano, że w sprawach tego rodzaju

\footnotetext{
${ }^{24}$ Art. 18 pkt 10 i 12 u.alkohol.

${ }^{25}$ Ustawa z 29 stycznia 2004 r. - Prawo zamówień publicznych, Dz. U. 2013, poz. 907 ze zm.
} 
maja zastosowanie art. 62 k.p.a. oraz art. 89 k.p.a. W tym modelu (załatwiania wniosków o zezwolenie na detaliczną sprzedaż napojów alkoholowych w jednym postępowaniu) porównuje się ze sobą szczegóły poszczególnych wniosków (lokalizacja sklepu oraz pozostałe okoliczności, istotne w świetle kryteriów ustalonych przez wójta gminy dla danego postępowania). Na koniec wydawana jest jedna decyzja adresowana zarówno do przedsiębiorcy, którego wniosek został uwzględniony, jak i do pozostałych stron, którym odmówiono zgody na sprzedaż napojów alkoholowych. Każda ze stron otrzymuje uzasadnienie sposobu załatwienia wszystkich wniosków, jakie były tym razem rozpatrywane.

Warto obecnie rozważyć zasadność wprowadzenia do art. 18 u.alkohol. kolejnej modyfikacji procedury poprzez poszerzenie zakresu przedmiotowego tej części postępowania, która toczy się przed gminną komisją rozwiązywania problemów alkoholowych. Już w chwili obecnej wnioski stron rozpatrywane są w pierwszej kolejności przez tę komisję, będącą organem pomocniczym wójta gminy $^{26}$. Jednak jej rola jest zredukowana do kontrolowania zgodności proponowanych lokalizacji sklepów z uchwałami rady gminy. Omówiona niżej zmiana polegałaby na przeprowadzeniu przez komisję (a nie - przez wójta gminy, jak to ma miejsce obecnie) postępowania w pełnym zakresie, celem zaproponowania wójtowi gminy treści decyzji załatwiającej otrzymane wnioski.

Procedurę zmierzająca do wydania zezwolenia, przewidzianego w art. 18 ust. $1 \mathrm{w} \mathrm{zw}$ z ust. 2 i 3 a ustawy, powinno poprzedzać podanie przez wójta gminy do publicznej wiadomości możliwości ubiegania się o nowe zezwolenie na sprzedaż napojów alkoholowych. W ogłoszeniu tym wskazany zostałby (a) termin (np. 14-dniowy) składania wniosków o wydanie takiego zezwolenia, (b) liczba zezwoleń, jakie tym razem mogą być wydane, a co najważniejsze (c) przedstawiony zostałby wyczerpujacy i zamknięty katalog kryteriów, na podstawie których wyłoniony zostanie wniosek pozytywnie załatwiony.

Po upływie wymienionego terminu przyjmowaniu wniosków byłyby one rozpoznane łącznie (w trybie art. 62 k.p.a.), w pełnym zakresie przez gminną komisję rozwiązywania problemów alkoholowych. Na tym etapie przeprowadzenie rozprawy (art. 89 k.p.a.) byłoby obowiązkowe, chyba że tylko jeden przedsiębiorca ubiega się o zezwolenia albo z innych przyczyn interesy prawne kilku wnioskodawców nie wykluczają się wzajemnie. W ten sposób mogłyby być wykorzystane najważniejsze atuty kontradyktoryjnego modelu rozpoznawania spraw. Efektem tej pierwszej części postępowania jurysdykcyjnego byłoby postanowienie (art. $123 \S 2$ in fine w związku z art. 106 k.p.a.) gminnej komisji rozwiązywania problemów alkoholowych wskazujące przedsiębiorcę, który powinien otrzymać zezwolenie. Należałoby nałożyć na komisję obowiązek wyczerpujaccego uzasadnienia faktycznego i prawnego postanowienia (art. $126 \mathrm{w}$ związku z art. 107 k.p.a.), mimo że na postanowienie to nie przysługiwałoby zażalenie (odstępstwo od art. $124 \S 2$ k.p.a.). Znaczenie tego postanowienia uzasadnia propozycję, by było ono doręczane zarówno wójtowi gminy,

${ }^{26}$ Art. 18 ust. 3a ustawy. 
jak i wszystkim stronom postępowania, czyli w tym postępowaniu nie miałby zastosowania art. 125 k.p.a.

W relatywnie krótkim terminie (7-14 dni) wójt gminy powinien zająć stanowisko w sprawie. Akceptując postępowanie przeprowadzone przez komisję oraz jej wynik, wójt gminy wydawałby decyzję kończacca postępowanie w I instancji w sprawie zezwolenia na sprzedaż napojów alkoholowych. Gdyby jednak postanowienie komisji było dotknięte istotnymi wadami materialnymi lub proceduralnymi, wójt gminy w drodze postanowienia uchylałby postanowienie komisji, przekazując jej sprawę do ponownego rozpoznania, a komisja byłaby związana oceną prawną i wykładnią prawa wójta gminy. Decyzja wójta gminy zatwierdzająca postanowienie komisji podlegałaby kontroli instancyjnej i sądowoadministracyjnej na ogólnych zasadach.

Aby powyższy model rozpatrzenia i załatwienia wniosków o zezwolenia na detaliczną sprzedaż napojów zawierających więcej niż 4,5\% alkoholu funkcjonował, konieczna byłaby zmiana kilku przepisów, zbliżająca ów model do konkursów. Najdalej idąca zmianą byłby wprowadzenie obowiązku wójta gminy podania do publicznej wiadomości wyczerpującego i zamkniętego katalogu kryteriów, przy zastosowaniu których wyłoniona zostanie strona otrzymująca pozwolenie. Taki tryb definiowania i podawania do wiadomości kryteriów jest możliwy już dzisiaj, ale nie jest obowiązkowy. Brak takiego ogłoszenia nie jest więc de lege lata żadnym uchybieniem, czyli taki brak nie może uzasadniać uchylenia decyzji przez sąd administracyjny. Zmiana nie zmieni dyskrecjonalnego charakteru rozdziału prawa do sprzedaży napojów alkoholowych, lecz uczyni ten wybór o wiele bardziej przejrzystym i bliższym modelowi administracji publicznej profesjonalnej i bezstronnej wobec konfliktu interesów stron postępowania.

Zasadniczo zmieniłby się katalog kompetencji proceduralnych gminnej komisji rozwiązywania problemów alkoholowych. Zastapiłaby ona wójta gminy $\mathrm{w}$ prowadzeniu pełnego postępowania jurysdykcyjnego $\mathrm{w}$ sprawie wniosków. Postępowanie przed komisją obejmowałoby wszystkie czynności przepisane przez Kodeks postępowania administracyjnego dla jurysdykcyjnego postępowania administracyjnego, z wyłączeniem kompetencji do wydania decyzji kończącej postępowanie w I instancji. Decyzję taką nadal wydawałby wójt gminy. Na gruncie obowiązującej ustawy komisja ma minimalny wpływ na wybór przedsiębiorcy, którego wniosek zostanie uwzględniony. Powierzenie komisji, będącej organem kolegialnemu, kompetencji do wyczerpujacego rozpoznania wniosków na rozprawie w obecności wszystkich wnioskodawców i wydanie na tej podstawie postanowienia-rekomendacji dla wójta gminy byłoby równie znaczącą i korzystną zmianą jak wcześniejsze zastosowanie łącznego rozpoznawania (w trybie art. 62 k.p.a.) omawianych tu wniosków.

Zaproponowane powyżej zmiany zmierzają do istotnego podwyższenia standardów załatwiania wniosków i zwiększenia przejrzystości procedury oraz zwiększenia gwarancji dla przestrzegania równości wnioskujących przedsiębiorców w dostępie do deficytowego dobra, jakim jest zezwolenia na detaliczną sprzedaż napojów zawierających więcej niż 4,5\% alkoholu. 


\section{PODSUMOWANIE}

Powierzenie wójtowi gminy, który dysponuje demokratyczną legitymacja polityczną uzyskaną w bezpośrednich wyborach, kompetencji do wydawania uznaniowych decyzji w sprawach indywidualnych nie zwalnia prawodawcy z obowiązku ochrony interesów prawnych adresatów tych rozstrzygnięć. W takich zewnętrznych stosunkach prawnych zachowuje swą aktualność negatywne domniemanie kompetencji materialnoprawnych, wyrażane syntetycznie hasłem „nic, co nie zostało wyraźnie prawem dozwolone, nie jest organowi administracyjnemu dozwolone" 27 . Z tego punktu widzenia samorząd terytorialny jest jedynie modelem demokratycznej metody obsadzania stanowisk, ale nie jest wystarczającą ochroną interesów prawnych stron, do których adresowane są uznaniowe decyzje organów samorządowych.

Gdy w postępowaniu jurysdykcyjnym uczestniczy tylko jedna strona, ochronie jej interesów służy zasada czynnego udziału strony w postępowaniu. Ta reguła nie jest wystarczająca, ilekroć w postępowaniu uczestniczy kilka stron ubiegających się o uzyskanie tego samego zezwolenia. Dlatego kryteria wyboru uwzględnianych wniosków nabieraja pierwszoplanowego znaczenia, co uzasadnia propozycję nałożenia na wójta gminy obowiązku podania tych kryteriów do publicznej wiadomości najpóźniej w dniu otwarcia procedury prowadzacej do wydania zezwolenia.

Podwyższeniu standardów załatwiania tego rodzaju spraw spornych służy również przeprowadzenie konkursu wniosków, poprzedzającego wydanie końcowej decyzji. Konkurs jest instytucją doskonale znaną i szeroko stosowana zawsze ilekroć przedmiotem rozstrzygnięcia jest wybór jednego kandydata, projektu, oferty itp. spośród kilku dostępnych. Nie znaczy to, że każda decyzja konstytutywna powinna być poprzedzona konkursem, gdyż nie każda taka decyzja polega na selekcji alternatyw rozłącznych (albo..., albo...). Przykładowo pozwolenie na budowę ma optymalnie ukształtować projektowaną inwestycję, a nie jest wyborem jednego z dwóch lub więcej kandydatów do inwestowania na tej samej działce. Nie każda sprawa zasługuje na przeprowadzenie pracochłonnego i kosztownego konkursu.

dr hab. Wiestaw Kisiel

Profesor Krakowskiej Akademii Andrzeja Frycza Modrzewskiego

wk052010@gmail.com

27 Już w 1993 r. NSA orzekł, że „[d]o działalności organów samorządowych w sferze zobowiązań publicznoprawnych [...] nie stosuje się zasady »co nie jest zakazane, jest dozwolone«, lecz zasadę "dozwolone jest tylko to, co prawo wyraźnie przewiduje«" (wyrok NSA z 24 maja 1993 r., III SA 2017/92, „Orzecznictwo Naczelnego Sądu Administracyjnego” 1993, z. 4, poz. 113). Ten pogląd nadal podtrzymywany jest w orzecznictwie sądów administracyjnych, por. uchwała NSA z 5 grudnia 2011 r., I OPS 4/11 (z glosą T. Kuczyńskiego, „Orzecznictwo Sądów Polskich” 2012, z. 6, s. 58), wyrok NSA z 11 sierpnia 2011 r., II OSK 925/11. 


\title{
PERMIT TO SELL ALCOHOLIC BEVERAGES: OPTIMISATION OF THE PROCEDURE OF ISSUING DECISIONS
}

\author{
Summary
}

Retail trade in alcoholic beverages may be carried out in Poland upon obtainment of an individual permit issued by the mayor of the respective municipality. The proposal presented in this paper is to modify the discretionary power of an administrative agency that issues such individual decisions. The criteria for successful application should be made public before the very first application is submitted.

For an applicant seeking an individual permit, a local self-government is nothing else but a model of democratic staffing of local public offices, not a safeguard of an individual's legal interests. Therefore, entrusting a local self-government entity with the authority to issue discretionary decisions in individual cases does not relieve the parliament of the responsibility to protect the addressees of discretionary decisions against arbitrary choices by a local self-government authority. Every time a local self-government decides on public law duties and prerogatives of an individual whilst not-being a unit of public administration, a negative presumption of competence should apply that "nothing, not expressly permitted by law is allowed to be used by an administrative authority.' 